\title{
Service Quality of Night Markets in Taiwan
}

\author{
Ching-Hsu Huang \\ Department of Hotel and Restaurant Management \\ National Pintung University of Science Technology, Taiwan, R.O.C. \\ E-mail: chinghsu@mail.npust.edu.tw
}

Received: March 31, 2012

Accepted: April 9, 2012 Published: June 1, 2012

doi:10.5539/ijms.v4n3p36

URL: http://dx.doi.org/10.5539/ijms.v4n3p36

\begin{abstract}
Night markets consist of contemporary societies strongly as a marketing style in Taiwan which is successful foodservice industry in spite of the limited space and remarkable crowding. Although the negative environment factors have been critiqued in terms of bad customer satisfaction, it seems the successful night markets demonstrate those are not applicable in Asia. The object of this study is to examine the customers' perspectives with regard to service quality of night market in Taiwan. The sample included 498 customers in night market. Based on five theoretical models of service quality, the night market service quality questionnaire was developed as the measurement of service quality for night market in Taiwan. The survey instrument consists of eight dimensions and 36 questions and data was randomly collected at top ten night markets elected by ballot. The study examined whether service quality perspectives differed across demographic segments. Age, occupation and income were found to significantly different. The location and the stay period of the night market were also significantly different in terms of service quality. The managerial implications of these findings for the food and beverage industry in night market and researchers are discussed.
\end{abstract}

Keywords: Service quality, Customer perspective, Foodservice industry, Night market

\section{Introduction}

The night market is one of the great success stories of tourism in East Asia Pacific region. It is essential to stand for the dining and living culture in many respects and has become one of the most popular attraction for international tourist in Taiwan since 2003 (Tourism Bureau, 2010; Enz, \& Siguaw, 2000; Chang et.al, 2007; Schutte, \& Ciarlante, 1998). In addition, night markets blended together different modes of analysis, such as food culture, marketing, service quality, economic, collectivist and tourism criticism (Wu \& Luan, 2007). The fast-food segment share of sales in commercial food consumed outside of the home rose from $28 \%$ to $45 \%$ between 1970 and 1990 (Tourism Bureau, 2010). In other words, the fast-food industry draws one-fifth of the consumer food dollars, including the food expenditure in night market. As a result, night market-food markets offer many growth opportunities for quick-service restaurant marketers. In regard to this market potential, the foodservices in night market often drive sales through tourism market positioning. Night marketers would like to know what influences customers', or the tourists' choice of foodservice in night markets. They have stretched their marketing strategies to focus on the development and packaging unique local meal, food, drinks, and to make the fast-food night market experience fun, interactive and memorable. Increasing the service quality in night markets was one of the strategies to attract the tourism from all over the world.

During the last decade researchers have endeavored to conceptualize and measure the service quality and gain a better understanding the consumer behaviors (Parsuraman, Zeithaml, et al., 1985, 1988). The majority of service quality research has been focused on measuring the customers' perception of quality service and developing numerous service quality models that related to customer satisfaction, expectation and perception (Stevens, Knutson, et al., 1995). Service quality and customer satisfaction has received dramatic attention in the hospitality marketing and management literature. While there has been some success in providing high quality service in restaurant industry, little service quality research on the unique food and beverage service has been conducted.

As such, this study concentrates on constructing a service quality scale for foodservice in night market with the measurement which addressed by different researchers. Based on this purpose, research hypotheses were formulated in terms of theoretically and empirically derived dimensions of service quality. The following null 
hypotheses are offered:

(1) There are no differences in service quality perspectives between across the demographic segments.

(2) There are no significant differences among the locations of night markets.

(3) Segments comprised of restaurateurs with similar service quality perspectives will not differ in their agreement ration of service quality measurement.

\section{Literature Review}

Parsuraman, Zeithaml, et al., (1985) introduced the service quality conceptual model for the service industry. They identified ten domains of service quality by tangibles: reliability, empathy, responsiveness, competence, courtesy, credibility, security, access, and communication. According to the PZB model, there are some gaps between customers' expected and perceived service quality. Furthermore, they defined SERVQUAL as an instrument for measuring the gap between the services that customers expect and what they actually perceive (Parasuraman, Zeithaml, et al., 1985, 1988). Five dimensions of SERVQUAL (assurance, responsiveness, tangibles, empathy, and reliability) provided the main structure for developing other service quality scales such as DINESERV and LODGSERV (Stevens, Knutson, et al., 1995; Knutson, Stevens, et al., 1996). Some researchers adapted the instrument SERVQUAL to the restaurant industry and used the lessons learned in developing and refining LODGSERV, a service quality index for the lodging industry (Knutson, Stevens, et al., 1990; Knutson, Stevens, et al., 1990). The instrument contained 40 statements, and the researchers used confirmatory factor analysis to purify the LODGSERV scale and confirm the five dimensions of service quality.

Restaurant service quality has recently become a global topic of inquiry, as researchers and experts engage in finding the best way of measuring or improving service quality for foodservice industry from such different aspects as customers' expectation vs. perception, managers, and service providers (MacLaurin \& Maclaurin, 2000; Palakurthi \& Getty, 1998; Lehtinen \& Lehtinen 1991). Over the last decade, there has been some discussion and controversial debate about the measurement of service quality or customer satisfaction for the purpose of benchmarking the quality of restaurant services (Kivela, Inbakaran, et al., 1999; Clow, Kurtz, et al., 1996; Ekinci \& Riley, 1998). The discussion and debate have focused on the measurement or improvement of restaurant service quality from different aspects, such as employee performance, customer perspective, the gaps in the service measurement model, and holistic viewpoints.

Past research of restaurant service quality has typically indicated different types of attribute variables that related to the components and concepts of service (Smith, 1994; Saleh \& Ryan, 1991). The concept service quality Gap model has been applied dramatically to the development of service quality measurement, customer loyalty, and behaviour in hotel sectors. Due to the difficulty of collecting the data of seller side associated with dyad studies, most of the previous studies were on the customer side (Hyun, 2010; Chen \& Hu, 2010; Ha \& Jang, 2010).

Researchers utilized different frameworks to develop the service quality instrument, such as Cost of Quality, Rapid Assessment Methodology, Quality Function Deployment and Importance-Performance Analysis (Yasin \& Yavas, 2001; Jeong \& Oh, 1998; Yasin, Czuchry, et al., 1996). Most of them regarded employees as the cornerstone of customer satisfaction and service quality, so the directors of foodservice operations thought that employee empowerment and delegated authority might improve service quality. Some studies tested an integrative model of service quality, guest loyalty, customer value and satisfaction to find ways of understanding customer needs and wants (Oh, 1999; Williams, 1999).

\section{Methodology}

\subsection{Sampling Method}

In order to find the sample that can represent the population precisely, the 1,068 customers/subjects were drawn from the customers who went to 10 night markets. The population of restaurant customers was defined as Taiwanese citizens over 12 years of age. In order to ensure an adequate sample out of the population to conduct the analyses in this study, the sample size must be determined before data collection. It was determined under $3 \%$ estimated error and .05 confidence level. They are the variance of the population, the margin of acceptable error, and the confidence level (Saunder, Lewis, et al., 1997). Eventually, a total of 1068 night market customers were decided before data collection.

These 10 night markets were chosen using proportionate stratified sampling to fulfill a precise representation of the population. The sample was comprised of customers who agreed to complete the surveys anonymously. It is desirable that subjects were chosen from night markets because it showed that they went to markets and were familiar with the foodservice products and services of night markets. 
The population or customer proportions of north, central, south, and east are $43.5 \%, 17.8 \%, 25.8 \%$, and $12.9 \%$ (Tourism Bureau, 2010). According to Table 1, no night market was chosen in the east part of the geographical location due to the small probability. Therefore, the number of subjects in each stratum was decided by recalculating according to the customer proportions of geographical location, which also are shown in Table 1, column 7.

\section{Insert Table 1 here}

In column (2), stratum', 1 means the night markets don't open every day and stratum 2 means the night markets open every day.

Columns 1 and 2 are the geographical locations of Taiwan, and the type of the night markets constitute the stratum from which separate restaurant samples are drawn. In column $3, \mathrm{~N}_{\mathrm{r}}$ represents the number of night markets in each stratum. Columns $4\left(\mathrm{P}_{\mathrm{r}}\right)$ and $5\left(\mathrm{n}_{\mathrm{r}}\right)$ give the proportions and the numbers of the night markets in each stratum. Under a proportionate allocation with a uniform sampling fraction of 10/261, columns $5\left(\mathrm{n}_{\mathrm{r}}\right)$ gives the night market sample sizes taken from each stratum. Columns $6\left(\mathrm{P}_{\mathrm{s}}\right), 7\left(\mathrm{P}_{\mathrm{s}}^{\prime}\right)$, and $8\left(\mathrm{n}_{\mathrm{s}}\right)$ indicate the proportions of subjects or customer population and the numbers of subjects/customers.

The total number of 1,068 subjects is from the equation calculation mentioned earlier. By using the similar sampling method, the numbers of night markets that open or didn't open every day in certain counties were determined for data collection. For each night market in the different geographical locations, the research assistants collected separately 523 questionnaires at the north location, 225 questionnaires at the central location, and 320 questionnaires at the south location in order to obtain the desired sample size of customers in night markets. They approached every second guest who finished dinner during the dinner time. Finally, this study employed accurately the proportionate stratified sampling in order to avoid the "over sample" circumstance. For example, only one of each set of subjects can answer the questionnaire. A total of 1068 customers are the samples in this study. Four hundred and ninety-eight usable responses were eventually available for the data analysis.

\subsection{Reliability and Validity of Measurement}

A modified service quality scale was employed in this study. Four different models of service quality of restaurants in different countries were combined to be the theoretical model of service quality in this study (Vanniarajar, 2009; Kim W.G. et al., 2009; Qin and Prybutok, 2009; Stevens et al., 1995). Based on four theoretical models of service quality, the eight dimensions are the series of measurement models to develop the questionnaire. The domains and items wordings are shown in Table 2. The domains are tangibles, reliability, responsiveness, assurance, empathy, food quality, price/value and communication.

Six customers in night marketed were invited to participate in a pilot-test interview. They were asked to answer three open-ended questions. By using open coding, response categories were created from the data to three open-ended questions (Strauss \& Corbin, 1990). This study involved a number of steps to assess content validity. First, the questionnaire was designed based on the relevant literatures in order to describe the domains of service quality theory. It is necessary to construct items to reflect the meaning associated with these concepts. Second, six experts in the field of night market management and consumer behaviour were invited to serve as panel members to assess the content validity of the questionnaire (Carmines \& Zeller, 1979). The concept is made clear in the survey, and the experts judged whether the measures fully represented the domain.

\section{Insert Table 2 here}

A pre-test of the questionnaire was conducted with 50 subjects prior to collecting the final data. They were asked to comment on the validity and readability of the questionnaire. A factor analysis with orthogonal varimax rotation was conducted for data reduction. Several modifications were made according to the subjects' suggestions and data analysis, but the overall format was not changed.

Coefficient alpha can be also derived as the expected correlation between an actual test and a hypothetical alternative form that may never be constructed (Nunnally, 1978). For assessing the internal consistency reliability, Cronbach's Alpha was calculated to examine the stability of each factor. Reliability coefficients for each factor were considered acceptable if their value was greater than or equal to 0.70 (Nunnally, 1978). The pretest and actual test were conducted and relatively high-stability coefficients have been found consistently for both tests. These coefficients indicated the internal consistency of the study. For the pretest, the values of Cronbach's Alpha are 0.81 and 0.90 in each part of the survey. These are similar with the coefficient alphas of the actual study; they are 0.88 and 0.92 . 


\section{Results}

Descriptive statistics, analysis of variance (ANOVA), and independent sample t-tests have been utilized to analyze the data. The descriptive statistics were computed on demographic data to explore the night market customers' profiles and their perspectives of service quality.

\subsection{Demographic of the Subjects}

Table 3 illustrates the profile of the customers in night market. Of the 498 respondents, there were 198 males, accounting for $39.8 \%$ of customers; the other $60.2 \%$ of them were females. According to the age groups of the customers, it seems the customers under 20 years old and between 21 to 20 years old accounted for the majority of respondents with $209(42.0 \%)$, and $32.7 \%$ of customers. From the 498 customers in the sampling frame, there were 284 students. About thirty-nine percent of the customers stayed one and half hour in the night market during their visit. Almost half of the customers earns less NTD 10,000 every month. Such demographic characteristics might address the majority of customers in night markets have the budget to consume during their visits. In terms of region, 229 customers were from north region, 145 customers were from middle region, and 124 customers were from south region.

\subsection{The Comparisons of Service Quality Perspectives}

An independent sample t-test and ANOVA were conducted to assess the significant differences of customers' service quality perspectives across the demographic segments. The results showed that customer perspectives regarding night market service quality differed from the different age group and rejected the hypothesis $1(\mathrm{~F}=$ $2.30 \mathrm{P}<.0001)$. The results also revealed that the occupation $(\mathrm{F}=10.46, \mathrm{p}<.0001)$, income $(\mathrm{F}=4.76, \mathrm{p}$ $<.0001)$, location $(\mathrm{F}=5.19, \mathrm{p}<.0001)$, and stay period $(\mathrm{t}=3.61, \mathrm{p}<.0001)$ were statistically significantly different.

\section{Insert Table 3 here}

One way ANOVA was used to assess the significant difference of customer perceptive and develop classifications of customer groups for might market segmentation that is a means of increasing marketing sales. Segments of customers from the same location were established. The results of analysis and further ANOVA test were shown in Table 4.

There are significant differences among the location in terms of the night market service quality in Taiwan, including the domains of tangible, price/value and communication. Of the three night market location clusters, this middle segment $(\mathrm{n}=145)$ had lowest mean of Tangible domain but regarded the price/value factors as important index of night market service quality. For these customers in northern night markets, they much cared about the food quality in the night market rather than tangibles. The customers from the Middle location $(\mathrm{n}=145)$ also placed little attention on tangibles but the customers in southern location regarded the tangible as a vital issue. Especially, there is significant different among those three locations in tangible, price/value, and communication domains. In addition, this study investigated the service quality perspectives of top 10 night markets in Taiwan, the foodservice operators in night markets can know how the competitors manage the service quality system in order to create their own market positioning.

\section{Insert Table 4 here}

\section{Discussion and Conclusion}

\subsection{Discussions and Implications}

The fundamental intent of this study was to suggest that food and beverage operators understand the customers' perspectives of service quality in night market. Even the modified service quality scale was conducted in night markets, the results confirmed that there are eight service quality dimensions of the foodservice business in night markets, namely Tangibles, Reliability, Responsiveness, Assurance, Empathy, Food quality, Price/value, and Communication. This result confirmed the results of earlier studies, including DINESERV, SERVPERF and other service quality scales (Vanniarajar, 2009; Kim W.G. et al., 2009; Qin and Prybutok, 2009; Stevens et al., 1995). Besides the basic five dimensions asserted by Stevens et al., (1995), three domains of service quality were found vital to service quality, namely Food quality, Price/value and Communication (Vanniarajar, 2009; Kim W.G. et al., 2009). Food quality is highly needed to enhance the overall service quality in the foodservice business in the night markets. Furthermore, those domains were found as the significant factors influencing the customer satisfaction across the institutional foodservice sectors (Kim, et al., 2009). The foodservice operators in night markets truly want to gain a winning game, they should continually to increase the level of overall service quality in terms of those eight domains. 
The encouraging results presented show that differences perspectives toward service quality among demographic segments were found. Basically customers subjectively interpret service quality according to their experience but service quality might be perceived as a server interpretation of his or her emphasis of night market food and beverage operation. These different interpretations might expand the gaps of customer expectation and actual service encounters operators provide. They also might lead to customer dissatisfaction. Based upon the results and implications obtained it is clear that it is important to understand the details of differences by comparing in difference factors.

Knowing what customers perceive service quality and what competitors/other operators engage in service quality management can help food and service business in night market to reach the goals such as identifying customers' needs and wants, differentiating themselves from competitors, enhancing customer loyalty, retaining existing customers, increasing repeat business, and building positive word-of-mouth. The results also imply that food and beverage marketers in night market should consider the differences or gaps when segmenting markets and planning communication strategies such as segmenting by age, occupation, income, location and stay period variables.

In addition to compare different service quality perspectives, this study was preliminary and served as a guide for future development of service quality measurements in night markets. Moreover, it also tried to lay a foundation for building a total service quality system for the food and beverage business in night markets in Taiwan. Even though periodic administration of DINESERV, the restaurant quality instrument, was recommend to restaurants to track the service quality trend (Knutson, Stevens, \& Patton, 1996), it is impractical for the food and beverage business in night markets in Taiwan to conduct these quality instruments because of cultural differences.

Identifying customers' needs and knowing the general perspectives of competitors will prepare restaurateurs to allocate their resources to achieve their business goals. In order to enhance Asia/Pacific Regional Operations Center's image in the world, the food and beverage operators in Taiwan should provide high service quality to customers by knowing the perspectives of customers and their own.

This study was undertaken as part of efforts to identify factors relevant to understanding the customers' perspectives of service quality in terms of food and beverage business in night markets. In addition, differentiating customer segments was also the other part of effort. Different perspectives of service quality enhance the different service practices and confirmation/disconfirmation. The findings supported the premise that there are differences in service quality perspectives across some of the demographic segments. In order to close service gaps and provide more effective and efficient food and beverage operation in night markets, the implications are applicable for food and beverage operation exercising strategies of marketing.

\subsection{Limitations and Suggestions for Future Research}

The limitations of this study provide some directions for further research. The nature of the foodservice industry in night markets is unique and different from other industries; further studies should develop the specific dimension of service quality for the night markets. To date, marketing research that is interested in hospitality and cultural per se is rare. Thus, cultural characteristics of customers and sellers are also recommended for the further dyad studies of service quality. Incorporating marketing theory into assessing the service quality model may result in models that offer more insight into the development of the hospitality industry. The goal of future research should be to build upon this description and delineate model processes, or causes and effects, inherent in different types of subjects. Such an effort should include identifying longitudinal relationships of seller-buyer and the consequences of consumptions patterns.

Even though this study employed an effective sampling methodology and sufficient sample size, as with any social science study, the sample and the design may still limit the generalizability of the findings drawn from this study. Generalizability of the findings should be done cautiously and cannot be generalized to whole population until results are replicated. On the other hand, while the level of effects may not be generalizability to other kinds of foodservice sectors, this study would argue that the structure of service quality among variables as hypothesized should be. The dimensions of service quality include tangibles, reliability, responsiveness, assurance, empathy, food quality, price/value and communication. In addition, previous studies put different dimensions in the service quality measurement model. The further studies should examine the measurement equivalence by using a multi-group confirmatory factor analysis approach, competing model strategies with structural equation or others.

Finally, these results were acquired from the subjects living in Taiwan and likely were prejudiced against the foodservice industry in night markets because of belief, dining culture, and values systems that may or may not be eccentric to other countries. Further research can find other secondary data including what this study has 
missed to make the sample more representative.

\section{Acknowledgement}

The National Science Council (NSC) of Taiwan, R.O.C. supported this study; under the grant number NSC100-2410-H-020-012.

\section{References}

Carmines, Edward G., \& Richard, A. Zeller. (1979). Reliability and Validity Assessment. Newbury Park, CA: Sage Publications.

Chang, J., Min, C.H., Lin, Y., \& Chiang, C. H. (2007). Profiling Japanese tourists visiting night markets in Taiwan. Journal of Quality Assurance in Hospitality and Tourism, 8(2), 25-44. http://dx.doi.org/10.1300/J162v08n02_02

Chen, P., \& Hu, H. (2010). How determinant attributes of service quality influence customer-perceived value: An empirical investigation of the Australian coffee outlet industy. International Journal of Contemporary Hospitality Mangement, 22(4), 535-551. http://dx.doi.org/10.1108/09596111011042730

Clow, K. E., Kurtz, D. L., \& Ozment, John. (1996). Managing customer expectations of restaurants: an empirical study. Journal of Restaurant \& Foodservice Marketing, 1(3/4), 135-159. http://dx.doi.org/10.1300/J061v01n03_09

Ekinci, Y., \& Riley, M. (1998). A critique of the issues and theoretical assumptions in service quality measurement in the lodging industry: time to move the goal-posts? International Journal of Hospitality Management, 17(4), 349-362. http://dx.doi.org/10.1016/S0278-4319(98)00032-2

Enz, C. A., \& Siguaw, J. A. (2000). Best practices in service quality. The Cornell Hotel and Restaurant Administration Quarterly, 41(5), 20-29. http://dx.doi.org/10.1177/001088040004100123

Ha, J., \& Jang, S. (2010). Effects of service quality and food quality: The moderating role of atmospherics in an ethnic restaurant segment. International Jouranl of Hosptiality Mangement, 29(3), 520-529. http://dx.doi.org/10.1016/j.ijhm.2009.12.005

Hyun, S. S. (2010). Predictors of relationship quality and loyalty in the chain restaurant industry. Cornell Hospitality Quarterly, 51(2), 251-267. http://dx.doi.org/10.1177/1938965510363264

Jeong, M., \& Oh, H. (1998). Quality function deployment: an extended framework for service quality and customer satisfaction in the hospitality industry. International Journal of Hospitality Management, 17(4), 375-390. http://dx.doi.org/10.1016/S0278-4319(98)00024-3

Kim, W. G., Ng, C. Y. N., \& Kim. Y. S. (2009). Influence of institutional DINESERV on customer satisfaction, return intention, and word-of-mouth. International Journal of Hospitality Management, 28(1), 10-17. http://dx.doi.org/ 10.1016/j.ijhm.2008.03.005

Kivela, J., Inbakaran, R., \& Reece, J. (1999). Consumer research in the restaurant environment, Part 1: A conceptual model of dining satisfaction and return patronage. International Journal of Contemporary Hospitality Management, 11(5), 205-222. http://dx.doi.org/10.1108/09596119910272739

Knutson, B., Stevens, P., Wullaert, C., \& Patton, M. (1990). Service expectation index: a discussion of confirmatory analysis and factor analysis as methods of index testing and refinement. Hospitality Research Journal, 14(2), 413-419. http://dx.doi.org/10.1177/109634809001400244

Knutson, B., Stevens, P., Wullaert, C., Patton, M., \& Fumito, Y. (1990). LODGSERV: A service quality index for the lodging industry. Hospitality Research Journal, 14(2), 177-284. http://dx.doi.org/10.1177/109634809001400230

Knutson, B., Stevens, P., \& Patton, M. (1996). DINESERV: measuring service quality in quick service, casual/theme, and fine dining restaurant. Journal of Hospitality and Leisure Marketing, 3(2), 35-44. http://dx.doi.org/10.1300/J150v03n02_04

Lehtinen, U., \& Lehtinen, J. R. (1991). Two approaches to service quality dimensions. The service Industries Journal, 11(3), 287-303. http://dx.doi.org/ 10.1080/02642069100000047

MacLaurin, D. J., \& MacLaurin, T. L. (2000). Customer perceptions of Singapore's theme restaurants. The Cornell Hotel and Restaurant Administration Quarterly, 41(3), 75-85. http://dx.doi.org/10.1177/001088040004100319

Nunnally, J. C. (1978). Psychometric theory. New York: McGraw-Hill. 
Oh, H. (1999). Service quality, customer satisfaction, and customer value: a holistic perspective. International Journal of Hospitality Management, 18(1), 67-82. http://dx.doi.org/10.1016/S0278-4319(98)00047-4

Qin, H., \& Prybutok, V. (2009). Service quality, customer satisfaction, and behavioral intentions in fast-food restaurants International. Journal of Quality and Service Sciences, 1(1), 78-95. http://dx.doi.org/10.1108/17566690910945886

Palakurthi, R. R., \& Getty, J. M. (1998). A procedure for scaling service quality tradeoffs among restaurant managers: traditional conjoint techniques for international application. Journal of International Hospitality, Leisure \& Tourism Management, 1(3), 3-19. http://dx.doi.org/10.1300/J268v01n03_02

Parasuraman, A., Zeithaml, V., \& Berry, L. (1985). A conceptual model of service quality and its implications for future research. Journal of Marketing, 49(4), 41-45. http://dx.doi.org/10.2307/1251430

Parasuraman, A., Zeithaml, V., \& Berry, L. (1988). SERVQUAL: A multi-item scale for measuring consumer perceptions of service quality. Journal of Retailing, 64(1), 12-40. http://dx.doi.org/10.1016/S0148-2963(99)00084-3

Saleh, F., \& Ryan, C. (1991). Analyzing service quality in the hospitality industry using the SERVQUAL model. The Service Industries Journal, 11(3), 324-345. http://dx.doi.org/10.1080/02642069100000049

Saunders, M., Lewis, P., \&Thomhill, A. (1997). Research Methods for business students. Great Britain: Pitman Publishing.

Schutte, H., \& Ciarlante, D. (1998). Consumer behavior in Asia. NY: New York University Press.

Smith, K. (1994). Blueprinting the restaurant for improved service quality. Journal of Hospitality and Leisure Marketing, 2(4), 21-35. http://dx.doi.org/10.1300/J150v02n04_03

Stevens, P., Knutson, B., \& Patton, M. (1995). DINESERV: A tool for measuring service quality in restaurants. The Cornell Hotel and Restaurant Administration Quarterly, 36(2), 56-60. http://dx.doi.org/10.1177/001088049503600226

Strauss, A., \& Corbin, J. (1990). Basics of qualitative research: Grounded theory procedures and techniques. Newbury Park, CA: Sage Publications, Inc.

Tourism Bureau. (2010). Annual report on tourism. Taipei, R.O.C.: Tourism Bureau, Ministry of Transportation and Communication.

Vanniarajan, T. (2009). Dineserv: A tool for measuring service quality in restaurants. Journal of Marketing \& Communication, 4(3), 41-52.

Williams, J. G. (1999). The impact of employee performance cues on guest loyalty, perceived value and service quality. The Service Industries Journal, 19(3), 97-118. http://dx.doi.org/10.1080/02642069900000032

Wu, C., \& Luan, C. (2007). Exploring crowing effects on collectivists's emotions and purchase intention of durable and non-durable goods in East Asia night markets. Journal of International consumer Marketing, 20(1), 5-18. http://dx.doi.org/10.1300/J046v20n01_02

Yasin, M. M., Czuchry, A. J., \& Dorsch, J. J. (1996). A framework for the establishment of an optimal service quality level in a hospitality operational setting. Journal of Hospitality and Leisure Marketing, 4(2), 25-48. http://dx.doi.org/10.1300/J150v04n02_03

Yasin, M. M., \&Yavas, U. (2001). Improving service quality in the hospitality industry: a framework. Journal of Hospitality \& Leisure Marketing, 7(4), 33-44. http://dx.doi.org/10.1300/J150v07n04_04 
Table 1. Proportionate stratified sample of night markets and customers

\begin{tabular}{|c|c|c|c|c|c|c|c|}
\hline (1) & (2) & (3) & (4) & (5) & (6) & (7) & (8) \\
\hline Stratum & Stratum ${ }^{*}$ & $\mathrm{~N}_{\mathrm{r}}$ & $P_{r}$ & $n_{r}$ & $\mathrm{P}_{\mathrm{s}}$ & $\mathrm{P}_{\mathrm{s}}^{\prime}$ & $n_{s}$ \\
\hline \multirow[t]{2}{*}{ North } & 1 & 45 & 0.17 & 2 & \multirow[t]{2}{*}{0.43} & \multirow[t]{2}{*}{0.49} & \multirow[t]{2}{*}{523} \\
\hline & 2 & 33 & 0.13 & 1 & & & \\
\hline \multirow[t]{2}{*}{ Central } & 1 & 67 & 0.26 & 3 & \multirow[t]{2}{*}{0.18} & \multirow[t]{2}{*}{0.21} & \multirow[t]{2}{*}{225} \\
\hline & 2 & 12 & 0.05 & 1 & & & \\
\hline \multirow[t]{2}{*}{ South } & 1 & 80 & 0.30 & 3 & \multirow[t]{2}{*}{0.26} & \multirow[t]{2}{*}{0.30} & \multirow[t]{2}{*}{320} \\
\hline & 2 & 6 & 0.02 & 0 & & & \\
\hline \multirow[t]{3}{*}{ East } & 1 & 12 & 0.05 & 0 & \multirow[t]{2}{*}{0.13} & \multirow[t]{2}{*}{0} & \multirow[t]{2}{*}{0} \\
\hline & 2 & 6 & 0.02 & 0 & & & \\
\hline & Total & 261 & 1.00 & 10 & 1.00 & 1.00 & 1068 \\
\hline
\end{tabular}

Table 2. The domains and items of foodservice service quality of night markets

\begin{tabular}{|c|c|}
\hline Domains & Items wording \\
\hline Tangibles & $\begin{array}{l}\text { Convenient location } \\
\text { Short walking distance } \\
\text { Cleanliness of facilities } \\
\text { Parking area } \\
\text { Appropriate illumination }\end{array}$ \\
\hline Reliability & $\begin{array}{l}\text { Providing service as promised } \\
\text { Sympathetic and reassuring } \\
\text { Accurate charge } \\
\text { On-schedule service }\end{array}$ \\
\hline Responsiveness & $\begin{array}{l}\text { Telling exact service time } \\
\text { Employees available to requests } \\
\text { Prompt service }\end{array}$ \\
\hline Assurance & $\begin{array}{l}\text { Answering questions completely } \\
\text { Makes you feel comfortable and confident } \\
\text { Makes you feel personally safe } \\
\text { Well-trained, competent, and experienced employees }\end{array}$ \\
\hline Empathy & $\begin{array}{l}\text { Convenient operating hours } \\
\text { Knowledgeable staff } \\
\text { Personal care of individual needs } \\
\text { Willingness of staff to always help } \\
\text { Friendly service by staff }\end{array}$ \\
\hline Food quality & $\begin{array}{l}\text { Clean and Healthy } \\
\text { Freshness of the food and beverage } \\
\text { Taste of food and beverage } \\
\text { Appearance of the food } \\
\text { A variety of food and beverage }\end{array}$ \\
\hline Price/value & $\begin{array}{l}\text { Good value for the price } \\
\text { Reasonable price item } \\
\text { Competitive price } \\
\text { Value worthy of price } \\
\text { Special discounts } \\
\end{array}$ \\
\hline Communication & $\begin{array}{l}\text { Consistent communication through } \\
\text { Newsletter or direct mail } \\
\text { Information about new events } \\
\text { Mass media advertisement } \\
\text { Telemarketing services }\end{array}$ \\
\hline
\end{tabular}


Table 3. Demographic characteristics of customers in night markets

\begin{tabular}{|c|c|c|}
\hline Customers $\mathrm{N}=498$ & $\mathbf{n}$ & $(\%)$ \\
\hline \multicolumn{3}{|l|}{ Gender } \\
\hline Male & 198 & $(39.8 \%)$ \\
\hline Female & 300 & $(60.2 \%)$ \\
\hline \multicolumn{3}{|l|}{ Age } \\
\hline$<20$ years & 209 & $(42.0 \%)$ \\
\hline $21-30$ years & 163 & $(32.7 \%)$ \\
\hline $31-40$ years & 61 & $(12.2 \%)$ \\
\hline $41-50$ years & 43 & $(8.6 \%)$ \\
\hline$>50$ years & 22 & $(4.4 \%)$ \\
\hline \multicolumn{3}{|l|}{ Occupation } \\
\hline Student & 284 & $(57.0 \%)$ \\
\hline Military and government personnel & 23 & $(4.6 \%)$ \\
\hline Industry & 20 & $(4.0 \%)$ \\
\hline Business & 38 & $(7.6 \%)$ \\
\hline Service industry & 65 & $(13.1 \%)$ \\
\hline Housewife & 23 & $(4.6 \%)$ \\
\hline Others & 45 & $(9.0 \%)$ \\
\hline \multicolumn{3}{|l|}{ Income per month ${ }^{*}$} \\
\hline Less than NTD 10,000 & 259 & $(52.0 \%)$ \\
\hline NTD $10,000-50,000$ & 196 & $(39.4 \%)$ \\
\hline More than NTD 50,001 & 43 & $(8.6 \%)$ \\
\hline \multicolumn{3}{|l|}{ Length of stay } \\
\hline Less than 1 hour & 93 & $(18.7 \%)$ \\
\hline 1-1.5 hours & 193 & $(38.7 \%)$ \\
\hline 1.6-2 hours & 125 & $(25.1 \%)$ \\
\hline More than 2 hours & 87 & $(17.5 \%)$ \\
\hline \multicolumn{3}{|l|}{ Region } \\
\hline North & 229 & $(46.0 \%)$ \\
\hline Central & 145 & $(29.1 \%)$ \\
\hline South & 124 & $(24.9 \%)$ \\
\hline
\end{tabular}

NTD:USD $=1: 30$

Table 4 . The cross table of service quality and location

\begin{tabular}{|c|c|c|c|c|c|}
\hline \multirow{3}{*}{ Domains } & 1 North & 2 Middle & 3 South & \multirow{3}{*}{$\begin{array}{c}\mathrm{F} \\
\text { Value }\end{array}$} & \multirow{3}{*}{$\begin{array}{c}\text { Post Hoc } \\
\text { tests }^{b}\end{array}$} \\
\hline & $(n=229)$ & $(n=145)$ & $(n=124)$ & & \\
\hline & Mean (S.D.) ${ }^{\mathrm{A}}$ & Mean (S.D.) ${ }^{\mathrm{a}}$ & Mean (S.D.) $)^{\mathrm{a}}$ & & \\
\hline Tangibles & $4.09(0.95)$ & $3.60(0.88)$ & $4.38(0.87)$ & $25.59^{* *}$ & $\begin{array}{c}1>2,3 \\
2<3\end{array}$ \\
\hline Reliability & $4.61(1.22)$ & $4.77(0.88)$ & $4.72(1.11)$ & 1.05 & \\
\hline Responsiveness & $4.41(1.41)$ & $4.32(0.92)$ & $4.58(1.15)$ & 1.52 & \\
\hline Assurance & $4.58(1.08)$ & $4.61(0.85)$ & $4.65(1.13)$ & 0.19 & \\
\hline Empathy & $4.27(1.13)$ & $4.23(0.89)$ & $4.45(1.18)$ & 1.60 & \\
\hline Food quality & $4.69(1.02)$ & $4.90(0.76)$ & $4.74(1.15)$ & 1.95 & \\
\hline Price/value & $4.59(1.24)$ & $4.65(1.21)$ & $4.16(1.29)$ & $6.26^{* *}$ & $1,2>3$ \\
\hline Communication & $4.40(1.10)$ & $4.27(0.88)$ & $4.09(1.36)$ & $3.22^{*}$ & $1>3$ \\
\hline
\end{tabular}

$\mathrm{a}=$ S.D. $=$ Standard Deviation; $\mathrm{b}=$ Post hoc tests based on Scheffe's $\mathrm{p}<.05$;

$* \mathrm{P}<=0.05 ; * * \mathrm{P}<=0.01$; from a 7 -point Likert scale 